\section{World government the answer?}

SIR - Following your identification of the need to strengthen international political and economic institutions (Nature 370, 83; 1994), I wish to draw your attention to a recent proposal for increasing the democratic accountability, and therefore the political legitimacy, of the United Nations (UN). The proposal, put forward originally by the World Federalist Movement, calls for the establishment of a UN Parliamentary Assembly, involving people appointed from national parliaments, as was originally the case for the European Parliament (and in its early form, the US Senate), that would, like them, eventually evolve into a directly elected body.

As at present constituted, the UN represents the interests of governments, especially those of the five permanent members of the Security Council. But its activities increasingly impinge directly on the lives of many millions of world citizens who are not represented in its decisionmaking process. This occurs, for example, through the imposition of punitive economic sanctions (Haiti, Iraq, Serbia), UNsponsored military action (the Gulf War), peace-keeping operations (Bosnia, Cambodia) and attempted disaster relief (Somalia, Rwanda). In these and other ways, the UN is already trying to act as a world government and, as highlighted by your leading article, there is indeed an urgent need for this role to be developed further. However, it is clear that the lack of democratic accountability is impeding the UN's ability to fulfil this role.

Ever since John Locke wrote his Two Treatises of Government (1689), it has been generally accepted (at least in the West) that if the lives and liberties of individuals are affected by the actions of government, they must be represented in that government. As Locke warned: "When anyone ... shall take upon them to make laws, whom the People have not appointed so to do, they make laws without authority, which the People are not therefore bound to obey" (Second Treatise of Government, para 212).

World government will be no different from any other kind of government in this respect, and, unless a way is found of giving the world's citizens a voice in its activities, the UN will continue to fail to meet many of its most important objectives owing, at least in part, to a perceived lack of political legitimacy.

The establishment of a UN parliamentary assembly, even if it initially had only a consultative role, would go a long way towards correcting the present democratic deficit in the organization of the UN, and therefore enhance its authority. In the longer term, such an institution might form the foundation for a genuinely democratic federal world government.
Finally, as a matter of practicality, it should be noted that a parliamentary assembly could probably be established in the short term as a "subsidiary organ" of the General Assembly (under Article 22 of the UN Charter), thereby avoiding the great difficulty of having to renegotiate the charter itself. Further information can be obtained from the World Federalist Movement, UN Office, 777 UN Plaza, New York, New York 10017, USA.

\section{A. Crawford}

1 Cochrane Road,

London SW193QP, UK

\section{Research squeeze}

SIR - After thirty years in medical academia, I'm not baffled by the 54 per cent drop in National Institutes of Health (NIH) grants for young scientists over the past eight years (Nature 370, 87; 1994). When asked why he robbed banks, Willie Sutton replied: "Because that's where the money is". Now known as Sutton's law, it is the most parsimonious explanation for the NIH fall-out.

The name of the game may be research but the real bottom line is money; money to support the investigator directly and, thereby, indirectly to support the investigator's institution. In the 1980s, NIH monies dried up relative to demand. For academic physicians, particularly the most junior (and least tenured), the way of soft money became a form of Russian roulette few could chance. Academic clinical practice generated hard money offering de facto tenure as secure, if not as prestigious, as the institutional tenure possible through research (grants).

So it is and it will get worse. Over the past few years, the economic pressures for managed health care have come to dominate most academic medical institutions in the United States. These pressures barely tolerate the costs of teaching, let alone research. Given this reality, the possibility of a research career for young academic physicians must continue to shrink to an option for a few, mostly in select institutions. The economics of managed health care will similarly affect career opportunities for $\mathrm{PhD}$ investigators in academic medical institutions. As soft money to support $\mathrm{PhD}$ research becomes scarcer, it must be replaced by hard money generated through institutional clinical practice plans. Such largesse is not the mentality of managed health care.

MarkW. Steele

School of Medicine,

3705 Fifth Avenue at Desoto Street,

Pittsburgh

Pennsylvania 15213-3417, USA
University of Pittsburgh,

\section{Life class}

SIR - Recent correspondence on the report of the "Pontifical Academy for Life" (Nature 368, 90; 1994) is reminiscent of the 13-year-old scientific controversy aroused by the US Senate hearings on "Human Life" (Science 212, 648; 1981). In this respect, the letter by J. A. Botella (Nature 370, 172; 1994) shows the lasting inconsistence of the Vaticanist arguments against contraception and abortion: (human) life, it is said, begins at the moment of conception, when the genetic material of two germ cells contributes to create a new individual, different from its parents. Then, as reiterated by Professor Jerome Lejeuné's followers, the human nature of the human being from conception is not a metaphysical contention, but plain experimental fact. The falacy of the assertion lies in embryological as well as in etymological and semantic grounds.

As stated by B. G. Boving (Science 213, $154 ; 1981)$, a fertilized egg is a single cell (zygote) prone to a series of developmentally regulated divisions bringing out two major prime components: the embryoblast (mostly bound to be a fetus, or two identical twins) and the trophoblast (which develops into membranes, placenta, and umbilical cord). All these cells and components are alive, human and have the same genetic mixture, but they can hardly be seen as a person or an individual human being (non divisible single entity). Hence the etymological falacy, which also involves a metonymical substitution of human cells for human person. Given the weakness of the scientific arguments, it is a surprise that Botella has to invoke some mysterious events to justify the sudden appearance of a person out of a fertilized egg. I suggest that the mystery of humanhood be rated first in the scientific agenda of the "Academy" for Life.

\section{Angel Pestaña}

Instituto de Investigaciones Biomédicas. CSIC, C/Arturo Duperier 4,

280029 Madrid, Spain

\section{Second sex?}

SIR - Apparently, no women have contributed enough over the 125 -year history of scientific excellence at Nature to warrant a female speaker at your celebration. The lack of female speakers is emphasized by the title of your symposium, "Our place in nature - the evolution of our world." You must be talking about a maledominated world that evidently has not evolved over the last 125 years.

\section{Georglana May}

Department of Plant Biology,

University of Minnesota,

1445 Gortner Avenue,

St Paul, Minnesota 55108-1095, USA 